\title{
Design of Web Based Fire Warning System Using Ethernet Wiznet W5500
}

\author{
Sri Safrina Dewi and Dedi Satria \\ Department of Computer Engineering, Universitas Serambi Mekkah, Aceh, \\ Indonesia \\ Elin Yusibani and Didik Sugiyanto \\ Department of Physics, Universitas Syiah Kuala, Aceh, Indonesia
}

\begin{abstract}
Purpose - The purpose of this paper is to develop prototype of the web-based home fire early warning system using Wiznet W5500 Ethernet module. This system protocol helps users in sending information of fire through the internet with the internet of things (IoT) method using Wiznet Ethernet module as communication media to the user.

Design/Methodology/Approach - This paper presents the design of web-based home fire early warning system using Wiznet W5500 Ethernet module. The system prototype is built using flame sensors, MQ-02 smoke sensors, and LM35 temperature sensors as input components. While on the processor side using Arduino Uno microcontroller as sensor data processing. Processed data is sent to the Ethernet module as a web server resulting in a web-based early warning information system with an alarm notification on the browser along with home location status information and sensor data.

Findings - This research produces a prototype of the web-based home fire early warning system using Wiznet W5500 Ethernet module that has been able to provide notification to the security officer housing.

Research Limitations/Implications - In the implementation of measurement, the information system only accesses one house detector or one fire location.

Practical Implications - This research produces a prototype of the web-based home fire early warning system using Wiznet W5500 Ethernet module that has been able to distribute data of temperature, smoke, and fire. Originality/Value - The development of fire monitoring systems using flame sensors, smoke sensors and integrated temperature sensors in internet-based communication systems of things via the Internet W5500 does not appear to have been published yet.
\end{abstract}

Keywords Information System, Fire Disaster, Early Warning System, Microcontroller

This research is supported by the Ministry of Research and Higher Education (Ristekdikti) in the form of a grant scheme for college cooperation research (PKPT). We are grateful to the Research Team from Universitas Serambi Mekkah and Universitas Syiah Kuala who have provided research support in the form of laboratory facilities and technical consultation.

(C) Sri Safrina Dewi, Dedi Satria, Elin Yusibani, and Didik Sugiyanto. Published in the Emerald Reach Proceedings Series. Published by Emerald Publishing Limited. This article is published under the Creative Commons Attribution (CC BY 4.0) licence. Anyone may reproduce, distribute, translate and create derivative works of this article (for both commercial and non-commercial purposes), subject to full attribution to the original publication and authors. The full terms of this licence may be seen at http://creativecommons.org/licences/by/4.0/legalcode

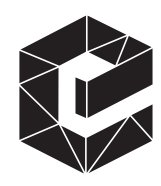

Emerald Reach Proceedings Series Vol. 1 


\section{Introduction}

Fire disaster is one of the most frequent disasters in Indonesia. Not only in densely populated areas but also the forest area is one area that can not be separated from the fire disaster. Fires often occur especially in densely populated areas that are on average influenced by electrical shortcuts and gas leaks in domestic kitchens. Many cases of fires are known at the time of the fire and little can be detected early.

Information on the occurrence of fires is obtained by residents around the fire location. To get fire assistance, community participation is needed to contact firefighters to anticipate fire disasters both housing and building. A community-based information system is a conventional system that is often done today. This system has the disadvantage that it takes time for the information to reach the fire department.

Based on a community-based information system that has been done at this time it is necessary to have a fire disaster information system that can provide notification and information in real-time in the form of information from the beginning of the condition of the source of fire and its location to the firefighters and the community effectively and efficiently.

From these problems then the purpose of this article is to discuss designing prototype web-based fire warning system using ethernet module communication lines

\section{Related works}

A number of previous studies have been conducted on early warning of natural disasters, as seen in technological diversions have made step-by-step shifts such as flood early warning systems that transmit flood height data in real-time (Satria et al. 2017a). The research produces output in the form of sending fire data sent through GSM module with output in the form of fire location information in the form of google maps. Other studies have done similar things in the use of Google Maps location-based information systems in flood detection systems (Satria et al. 2017b). Implementation of fire detection system has been done in previous research with various differences such as the design of mobile application called "Informer on Site", this application is a prototype that aims to provide disaster information which focused on disaster cases such as flood, typhoon, smog, and landslide. This application can help the authorities handle disasters more effectively and quickly (Nik Nazli et al. 2016). The use of GSM applications for other fire information has been built that is an automatic fire detection and rescue system based on Wireless Sensor Network (WSN) technology. Research using PIC16F877A microcontroller, temperature and gas sensors that provide continuous information remotely using Wireless Sensor Network model through GSM communication (Deepika \& Yuvaraju 2015). While the next research using GSM communication system is the design of fire accident control system on the train. This research uses various sensors such as temperature and gas sensors to monitor fire to Global System for Mobile Communication (GSM) (Yuvaraju et al. 2016). In contrast to Nweke Chisom implementation of Global Positioning System (GPS) in reporting the incident of fire, with its location in real-time mode. This app is designed using the smoke sensor, heat sensor, microcontroller, GPS and SIM908 with the result of coordinate location sent to receiver cellular phone (Chisom and Ihekweaba 2014). The use of fire detection systems with use for GSM-based trains have also been built in the form of automatic fire detection and rescue system based on Wireless Sensor Network (WSN) technology to monitor and observe 
temperature and gas information. The application sends information when the fire is detected to a surveillance center of Global System for Mobile Communication (GSM ). By using automatic fires sprinkler system can be postponed automatically and emergency windows will be opened automatically so that passengers can be saved from windows (Nandhini et al. 2017).

\section{Design prototype}

The design of the system prototype is done in two stages namely the design stage of the fire detector system and the design stage of the fire location information system. In the design of fire detectors there are several integrated modules including the input components such as smoke sensors, temperature sensors, and GPS as coordinate detection, on the side of data processing components using Arduino Uno microcontroller and ends with the output component in the form of Ethernet Wiznet W5500 as sender data to the server information system fire location, as seen in the block diagram of Figure 1. detects the object's distance by emitting ultrasonic waves $(40 \mathrm{KHz})$ during $\mathrm{t}=\min 10$ us and then detecting the reflection (Asadullah et al., 2017).

In the block diagram of the Google Map-based location information system as shown in Figure 2, it can be explained that data sent by the fire detector remotely will be received by the Access Point and processed on the PC computer. Data processing is processed in the MySQL database as a system management database using Gammu tables and location tables. The result of the relation between the two tables is integrated with PHP programming and Google Map API so as to produce output in the form of the information system of web-based fire location.

\section{Results and discussion}

Based on the design of the prototype of the block diagram Fire detector system as shown in Figure 1, the resulting prototype system is the integration of several modules of the smoke

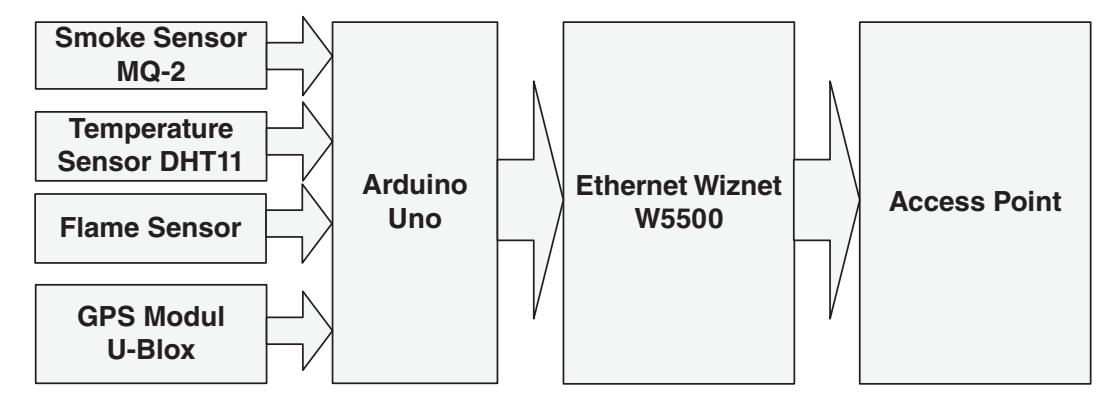

Figure 1.

Block Diagram of the

Wiznet W5500

Wiznet Ethernet Fire

Detector System

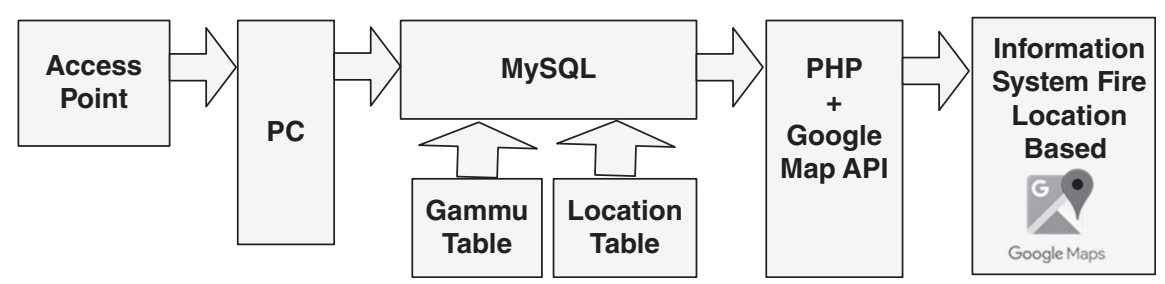

Figure 2.

Block Diagram of Information System

Fire Disaster

Location Based on

Google Map 
Proceedings of MICoMS 2017

\section{0}

Figure 3.

Prototype Result of Location Based Fire Detection System

Figure 4.

Experiments of Temperature and Smoke Detection Process using Paper Burning Media
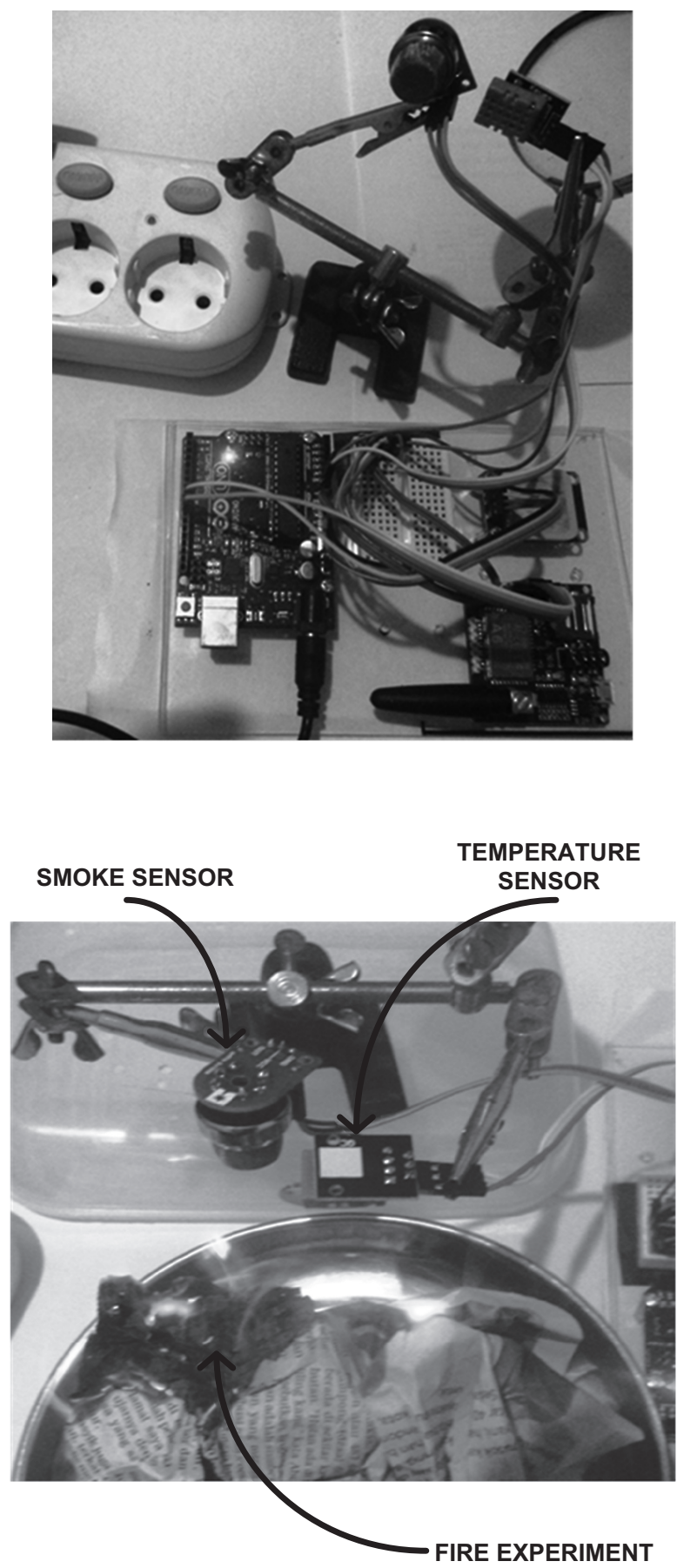


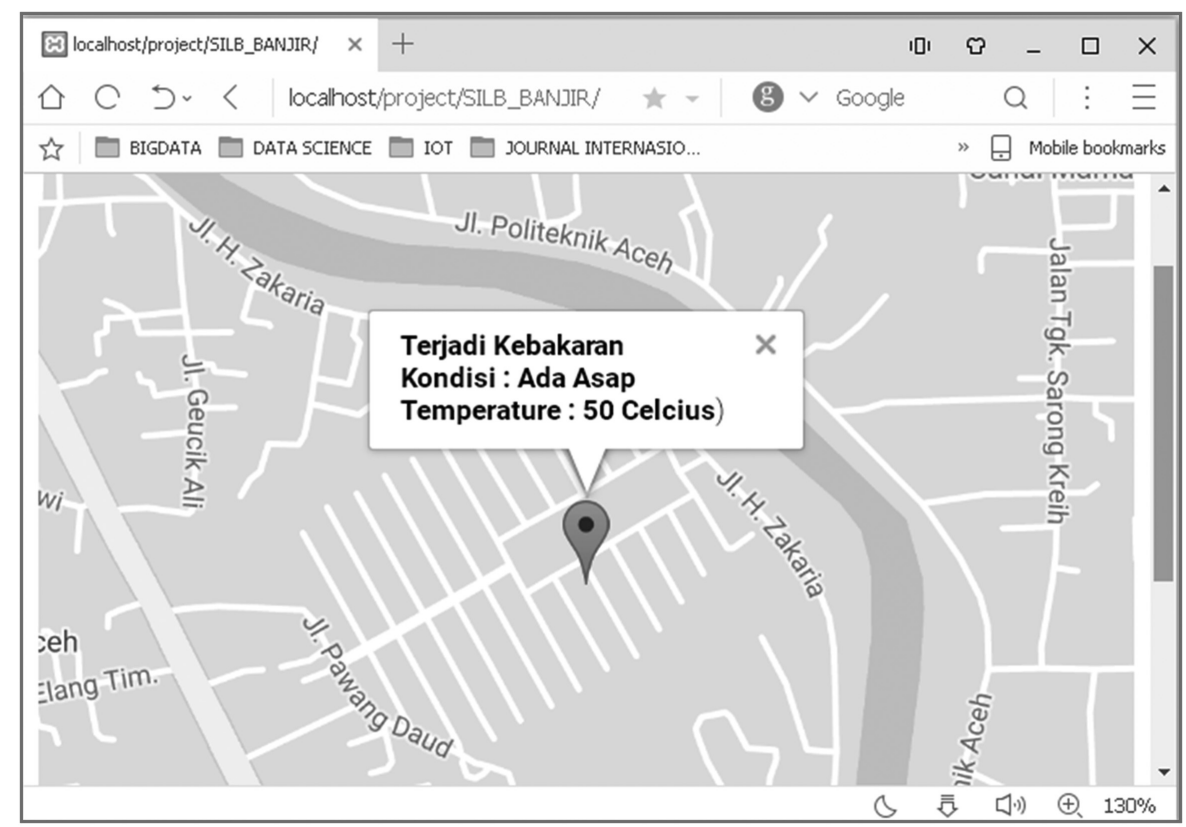

Design of Web

Based Fire

441

Figure 5.

Google Maps-based Fire Information

sensor which produces the data onto the presence of smoke, a temperature sensor that produces temperature data connected to analog pins on Arduino Uno microcontroller and a GPS module that generates location coordinates data as the input port connected to the RX pin of the Arduino Uno microcontroller as the data processing part of the presence of smoke and temperature as shown in Figure 3 . The data has been processed by the microcontroller to send data onto the form of coordinating data onto Ethernet Wiznet W5500.

The system usage experiments were carried out using a metal paper plate containing the paper. A further paper is burned to produce smoke and an increase in temperature is detected by temperature sensors and smoke sensors. The experimental form produces smoke and the process of temperature rises can be seen in Figure 4. Besides, the fire detector damage caused by the fire is neglected. This is because at the beginning of the fire smoke and temperature data has been sent before the tool burned.

From the experimental results from Figure 4, the data sent to the server generates the location information about the fire to the browser in the form of coordinating of location based on Google Maps. on the information is displayed info of a fire from the condition of the data onto smoke and temperature data at the time of fire occurred as shown in Figure 5.

\section{Conclusions}

Based on the results and discussion of this research it can be concluded that the prototype of fire monitoring information system has been successfully built in two systems namely fires detection system and fire location information system based on Google Maps. Both systems have been running in accordance with the experiments that have been done so as to produce information on the location of the location of the fire along with the condition data onto the smoke and temperature. And it is hoped that with this prototype development research, the 
Proceedings of community or parties related to the fire disaster can be helped to anticipate the bigger MICoMS 2017 disaster and take many casualties.

\section{References}

Asadullah, M. et al., (2017), "Smart Home Automation System Using Bluetooth Technology 2017", International Conference on Innovations in Electrical Engineering and Computational Technologies (ICIEECT), pp. 1-6.

Chisom, N. and Ihekweaba, O. (2014), Application of Gsm / Gps in Reporting of Fire Outbreak. Integrated Journal of Engineering Research and Technology, (Ed.1(5)), pp. 192-198.

Deepika, and Yuvaraju, (2015), "Wireless Sensor Network Based on GSM for Automatic Fire Detection and Rescue System in", International Journal of Engineering Research \& Technology (IJERT), (Ed. 4(11)), pp. 543-545.

Nandhini et al., (2017), "Development of Automatic Fire Detection and Rescue System using GSM", International Journal of Advanced Research in Computer and Communication Engineering (IJARCCE), (ed. 6(4)), pp. 689-694. Available at: http://ijarcce.com/upload/2017/april-17/ IJARCCE131.pdf.

Nik Nazli, N., Nadian, N., Sipon, S. and Norwawi, N.M. (2016), “A Prototype Mobile Application for Informing Disaster Complaint - "Informer on Site." International Journal of Interactive Mobile Technologies (iJIM), (Ed. 10(1)), pp. 68-70. Available at: http://online-journals.org/index.php/ i-jim/article/view/4737.

Satria, D. et al., (2017a), "Flood Early Warning System Based Arduino and Ethernet", Jurnal JTIK (Jurnal Teknologi Informasi dan Komunikasi), (Ed. 1(1)), pp. 1-6, Available at: http://journal. lembagakita.org/index.php/jtik.

Satria, D. et al., (2017b) "Prototype of Google Maps-Based Flood Monitoring System Using Arduino and GSM Module", International Research Journal of Engineering and Technology (IRJET), 4(10), pp. 1044-1047.

Yuvaraju, M., Naraina, A. and Deepika, K. (2016), "Wireless Based on Perfunctory Fire Detection and Liberate system", International Research Journal of Engineering and Technology (IRJET), 3(6), pp. $468-472$.

\section{Corresponding author}

Dedi Satria can be contacted at dedisatria@serambimekkah.ac.id 